\title{
Velocity well logs statistical analysis of the Itanhaém and Guarujá Formations, Santos Basin, Brazilian offshore
}

Pedro Benac* (Petrobras); Lívia Falcão (Petrobras); María González (Emerson); Vitor Novellino (Petrobras); Alexandre Maul (Petrobras); Carlos Eduardo Pereira (Petrobras) and Rejhane Cunha (Petrobras)

Copyright 2021, SBGf - Sociedade Brasileira de Geofísica

This paper was prepared for presentation during the $17^{\text {th }}$ International Congress of the Brazilian Geophysical Society held in Rio de Janeiro, Brazil, $16-19$ August 2021

Contents of this paper were reviewed by the Technical Committee of the $17^{\text {th }}$ International Congress of the Brazilian Geophysical Society and do not necessarily represent any position of the SBGf, its officers or members. Electronic reproduction or storage of any part of this paper for commercial purposes without the written consent of the Brazilian Geophysical Society is prohibited.

\begin{abstract}
The rock velocities distribution knowledge of a sedimentary basin is of great importance for many purposes, such as seismic acquisition and seismic processing, especially during the migration procedures and seismic interpretation studies. In order to achieve good results for these needs, it is increasingly necessary to obtain even more realistic and detailed velocity models. It is essential to get an a priori geological understanding of vertical and lateral velocity behaviors of the main stratigraphic units, especially those ones situated above the zones of interest, in our case the pre-salt reservoirs section in the Santos Basin. In this work, a comprehensive view of the sonic velocity logs statistical analysis was achieved based on data of 29 wells that only cover the Itanhaém and Guarujá Formations. Those formations represent large portions of the Cenomanian and Albian sections, situated above the evaporitic section (Ariri Formation), encasing most of the pre-salt reservoirs in that portion of the referred basin. Pelitic rocks characterize the Itanhaém Formation, and it is a typical record of intercalation of marls and shales deposited within a low energy context. The Guarujá Formation is composed of a great variety of carbonates like grainstone, mudstone and marls, deposited in an internal and external carbonate shelf context. Looking at the rock variation present in such formations, it sounds natural to imagine how heterogeneous the velocity property behavior is when looking at everything together. Therefore, we quantified the proportion by lithologies of the two mentioned formations carrying out the instantaneous velocity distributions in each separated lithology, that were previously classified using sample cuttings description. We also analyzed, mainly by cross plots, the relation of compressional velocity with other geological variables, as the burial effect separated by lithologies, paleo-basin portion. We brought the results mainly in the form of tables, histograms and pie charts, in order to elucidate the descriptive statistic of the velocity well-log information. The obtained results intend to be useful in supporting future studies of statistical inference in seismic velocities for the post-salt carbonates in the Santos Basin. As well as providing a statistical basis for initialization of the velocity models in seismic illumination and processing projects, elastic properties characterization studies, seismic inversion, geomechanical modeling and studies of geohazards. All of them focused on the pre-salt section.
\end{abstract}

